\title{
SUSTAINABLE WATER MANAGEMENT IN KUWAIT: CURRENT SITUATION AND POSSIBLE CORRECTIONAL MEASURES
}

\author{
A. MUKHOPADHYAY \& A. AKBER \\ Water Research Center, Kuwait Institute for Scientific Research, Kuwait.
}

\begin{abstract}
Kuwait, an arid country, has no surface source of useable water. It mainly depends on desalination plants for its freshwater needs. Brackish groundwater (salinity $<5000 \mathrm{ppm}$ ) is used for irrigation and mixing with desalinated water. At the current rate of increase in demand for freshwater, large investment is necessary at close intervals to augment the desalination capacity of the country. With very little natural replenishment, the aquifers yielding the brackish water are also under great stress. Management of both supply and demand is necessary to solve these problems. In addition to the increase in desalination capacity, supply may be augmented by the increased use of renovated wastewater, storage of seasonally higher supply of usable water in the aquifers through artificial recharge, establishment of integrated water transport network through the Gulf Cooperation Council (GCC) countries and exploration of new useable groundwater resources both onshore and offshore. Possible new sources of water are harvesting of rainfall runoff in the wadis and depressions and runoff carried by the storm water network within the urban areas, moisture recovery from the vadose zone, and the paleo-groundwater possibly preserved under the Arabian Gulf. Demand may be curbed through maintaining lower pressure in the water network and some form of rationing, reduction of network loss through adoption of appropriate measures, implementation of updated water code that will help in saving water, control of population through tighter immigration measures and reduction in government subsidy. Finally, water authorities should take steps to increase public awareness about all aspects of water management outlined before in real earnest.

Keywords: artificial recharge, brackish water, desalinated water, groundwater, runoff harvesting, wastewater
\end{abstract}

\section{INTRODUCTION}

Kuwait, situated in an arid belt that stretches through the Middle East and North Africa (Fig. 1), has no surface source of useable water. There is only a limited reserve of fresh groundwater in lenses floating over brackish to saline water in north Kuwait. Kuwait depends on desalination plants for the bulk of its freshwater needs. Brackish groundwater (salinity $<5000 \mathrm{ppm}$ ) extracted in the central and southwestern parts of Kuwait is used for irrigation and for mixing with the desalinated water to make it potable. The demand for fresh water is increasing at rapid rate. If this trend continues unchecked, a large investment will be necessary in the near future to augment the desalination capacity of the country. Aquifers yielding the brackish water are also under great stress, as there is very little natural replenishment for them. Judicious management of the available supplies and demands is the call of the day.

\section{SOURCES OF WATER}

Rainfall is scarce in the country (110 mm on average annually) and most of it evaporates under high ambient temperature (average annual evaporation more than $3000 \mathrm{~mm}$ ). Most of the useable groundwater, extracted in the southwestern parts of the country, is brackish (salinity 2500-5000 mg/l). Only in the two large surface depressions of Raudhatain and Umm Al-Aish in the northern part of the country, enough infiltration from the runoff accumulations formed during occasional intense rainstorms occurs to give rise to two near-surface freshwater lenses floating over the brackish to saline groundwater (Fig. 2). No surface water 


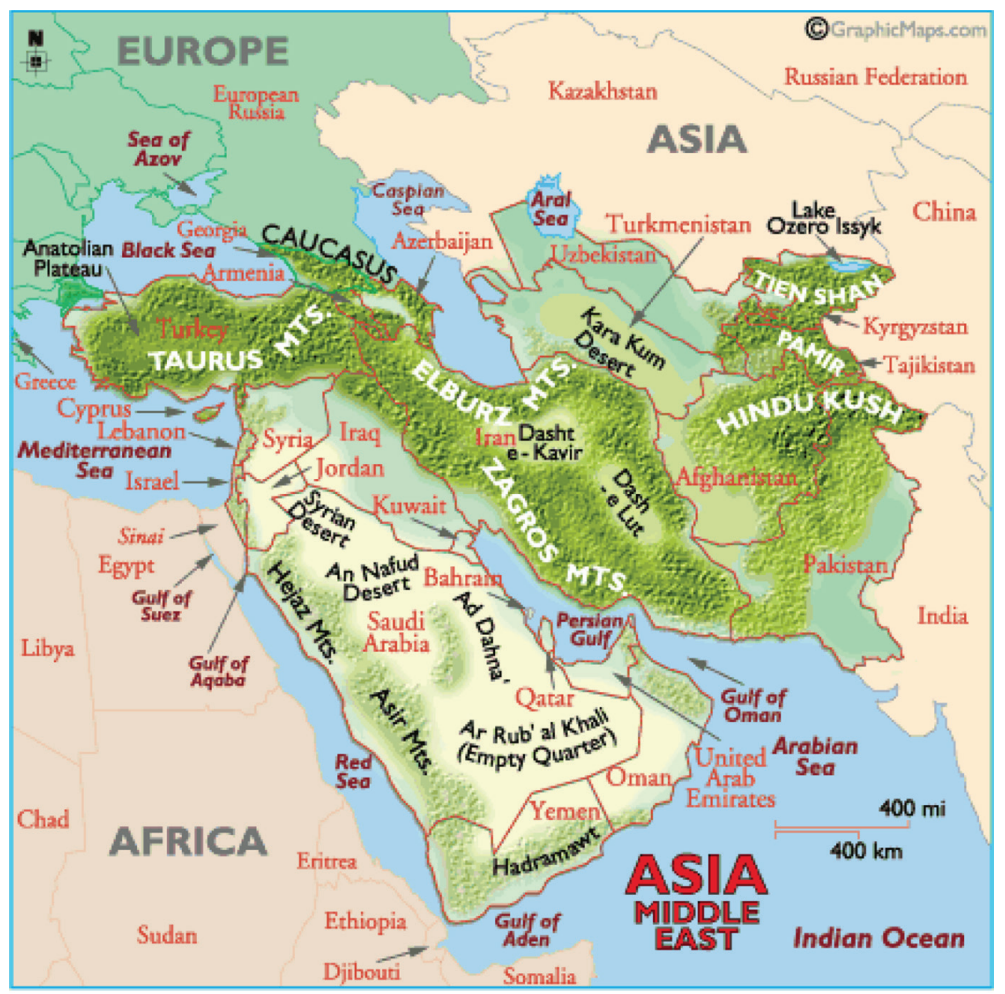

Figure 1: Location of Kuwait (courtesy of www.worldatlas.com).

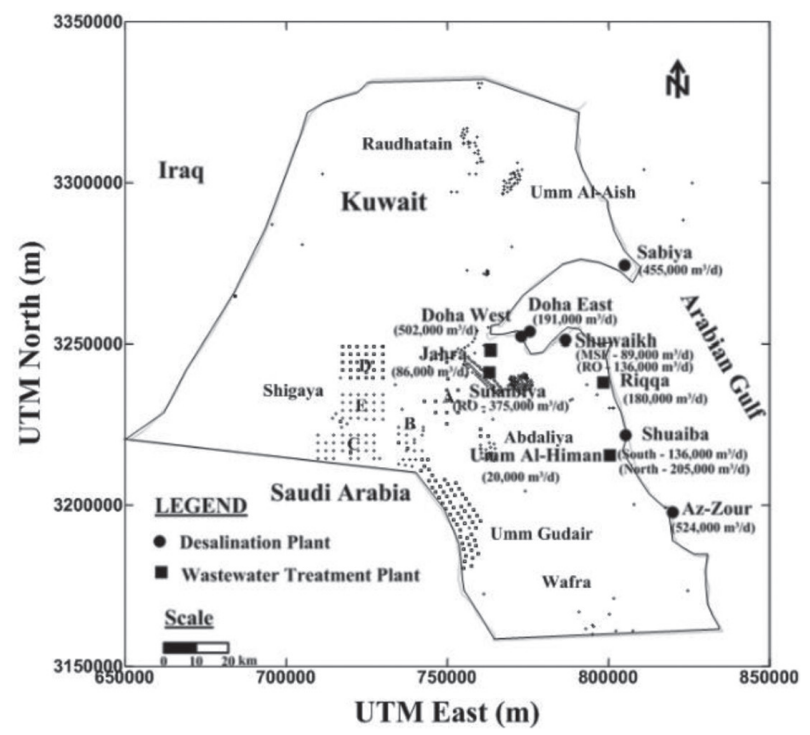

Figure 2: Water fields and desalination and wastewater treatment plants of Kuwait. 
(rivers or lakes) exists within the perimeter of the country. For its freshwater needs, Kuwait, therefore, mainly depends on the distillation of seawater.

Municipal wastewater in Kuwait is generally treated to tertiary level. Recently, membrane (reverse osmosis, RO) treatment has been introduced to renovate the municipal wastewater that produces very high-quality water. The treated wastewater is thus a very good additional resource for the country.

\section{CURRENT STATUS OF WATER AVAILABILITY AND CONSUMPTION}

\subsection{Desalinated water}

The installed capacity of desalination plants in Kuwait (Fig. 2) in 2014 was 528 MIG/d (2.40 $\mathrm{Mm}^{3} / \mathrm{d}$ ) [1] (Fig. 3). The average daily demand stood at $398 \mathrm{MIGPD}\left(1.81 \mathrm{Mm}^{3} / \mathrm{d}\right.$ ) at the same time, with the maximum consumption during September 2014, hitting 450 MIGPD $\left(2.05 \mathrm{Mm}^{3} / \mathrm{d}\right)$. The average per capita consumption in that year was $442 \mathrm{l} / \mathrm{d} /$ capita (Fig. 3). As noted by Burney et al. [2] compared with industrialized and other developing countries, the average annual freshwater consumption in Kuwait ( $450-500$ 1/d/capita) is very high (Fig. 3).

The freshwater consumption in Kuwait has a strong seasonal variation. This is illustrated in Fig. 4, which indicates that during the hottest months of the year (June-September), the consumption of freshwater is on average $15-25 \%$ higher than the yearly average.

\subsection{Groundwater}

Brackish groundwater is mainly used for irrigation and landscaping, livestock rearing, construction work, non-potable use in households, and for mixing with desalinated water at ratios of up to $10 \%$ of the total volume to make the mixture potable [2]. The production of brackish water reached its peak in 2006 (36,234 MIGPD; $\left.164.7 \mathrm{Mm}^{3} / \mathrm{d}\right)$, after which there

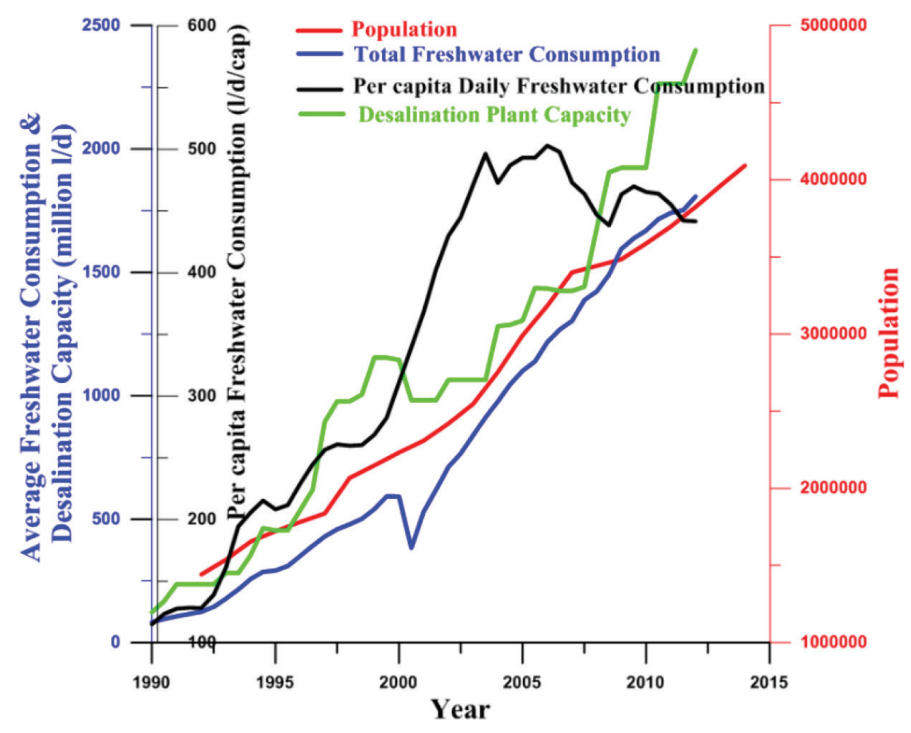

Figure 3: Development of installed desalination capacity, population and water consumption in Kuwait. 


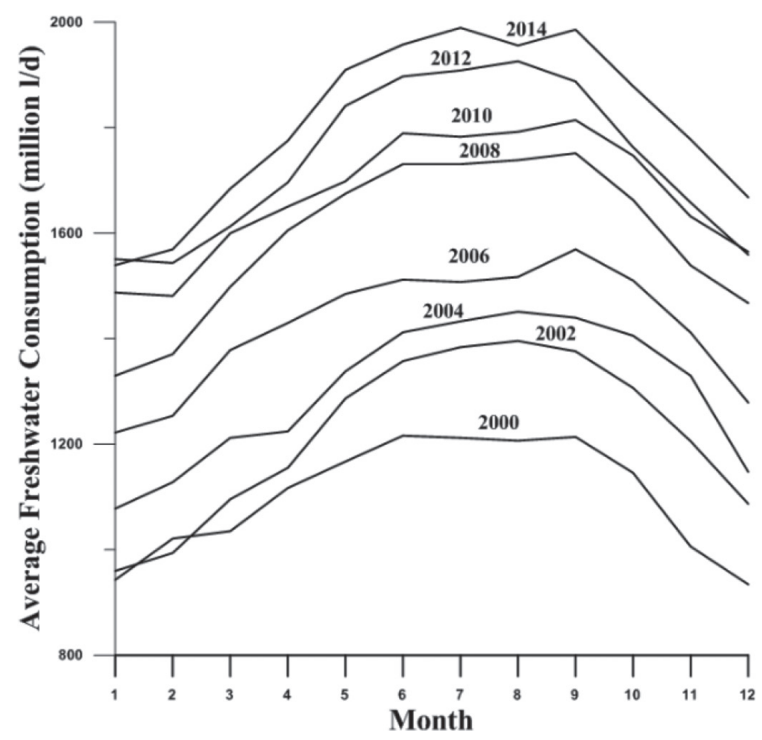

Figure 4: Seasonal variation of water consumption in Kuwait.

was a gradual decline in response to the availability of treated wastewater for irrigation and the awareness within the Ministry of Electricity and Water (MEW) about the need to preserve this strategic resource for posterity (Fig. 5). As of 2014, MEW and the Kuwait Oil Company (KOC) were producing annually 17,996 MIG $\left(81.8 \mathrm{Mm}^{3}\right)$ and 1,663 $\mathrm{MIG}\left(7.6 \mathrm{Mm}^{3}\right)$ of brackish water, respectively (MEW, 2015), giving an average daily production of 53.9 MIGPD $\left(244,849 \mathrm{~m}^{3} / \mathrm{d}\right)$. The maximum daily net consumption of brackish water during the

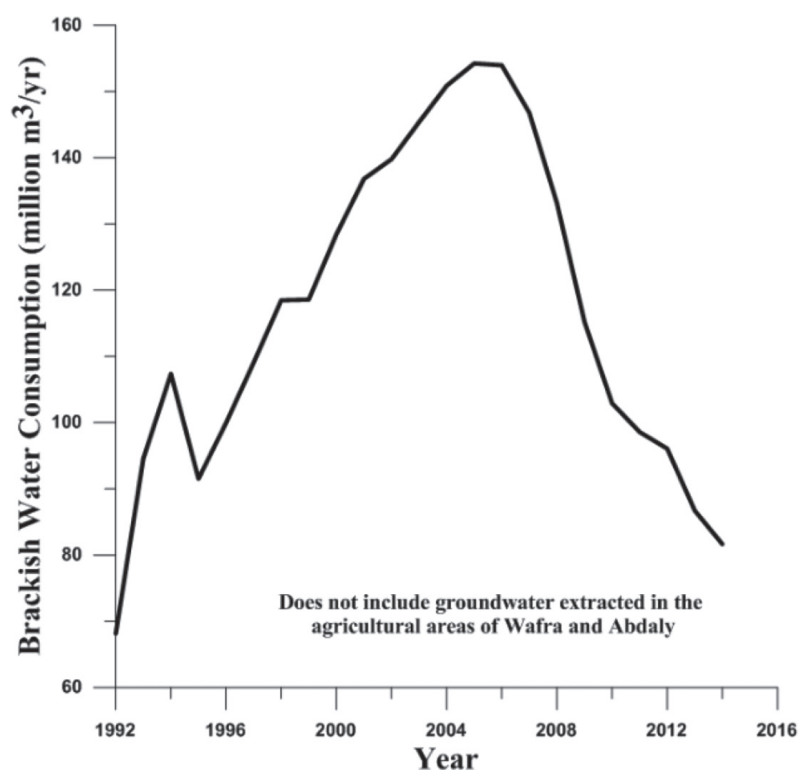

Figure 5: Development of brackish water consumption in Kuwait. 
summer of 2014 reached 73.8 MIGPD $\left(335,495 \mathrm{~m}^{3} / \mathrm{d}\right)$ with a yearly average of 52 MIGPD $\left(236,392 \mathrm{~m}^{3} / \mathrm{d}\right)$ [1]. The average production from the Wafra and Abdali farm wells, as estimated in 1989, was on the order of $200,000 \mathrm{~m}^{3} / \mathrm{d}$ from each of the areas $[3,4]$. The current withdrawals of groundwater are estimated to be $300,000-400,000 \mathrm{~m}^{3} / \mathrm{d}$ in each of the areas. The drop in potentiometric head in the Dammam Formation aquifer due to brackish water withdrawal since 1970s is shown in Figure 6.

In the freshwater fields of Raudhatain, the initial production at a rate slightly above 2 MIGPD (9090 m³ d) over the period 1963-1967 was reduced to about 1 MIGPD (4545 m²/d) to control the rising total dissolved solids (TDS) in the produced water. By 1989, total withdrawal from the two freshwater fields during the year declined to 24 MIG $\left(109,105 \mathrm{~m}^{3}\right)$, approximately 66,000 IG/d (300 m³/d). During the Iraqi occupation of 1990-1991, the field facilities were destroyed. Subsequently, hydrocarbon pollution of the freshwater lens at the Umm Al-Aish field, caused by the damaged oil wells, was detected. As a result, the Umm Al-Aish field has been abandoned. The Rawdatain Bottling Company is currently producing water at a maximum rate of up to 0.5 MIGPD $\left(2275 \mathrm{~m}^{3} / \mathrm{d}\right)$ from the Raudhatain field with no production by MEW.

\subsection{Renovated wastewater}

The total average treated effluent of municipal wastewater at the two major conventional treatment plants in operation (Riqqa \& Jahra, Fig. 2) was about 226,000 m³/d in 2005 [5]. About half of it was discharged to the sea and the rest was used for agriculture and landscaping.

Based on the study by Abdel-Jawad et al. [6], a municipal wastewater treatment plant using the reverse osmosis (RO) process and constructed by a private consortium on Build - Operate - Transfer (BOT) formula, has come into operation in Sulaibiya in 2004. The plant has a design capacity of $375,000 \mathrm{~m}^{3} / \mathrm{d}$. It accepted an inflow of $355,102 \mathrm{~m}^{3} / \mathrm{d}$ and produced $306,218 \mathrm{~m}^{3} / \mathrm{d}$ of treated effluent during 2006 [5]. The volume of wastewater generated

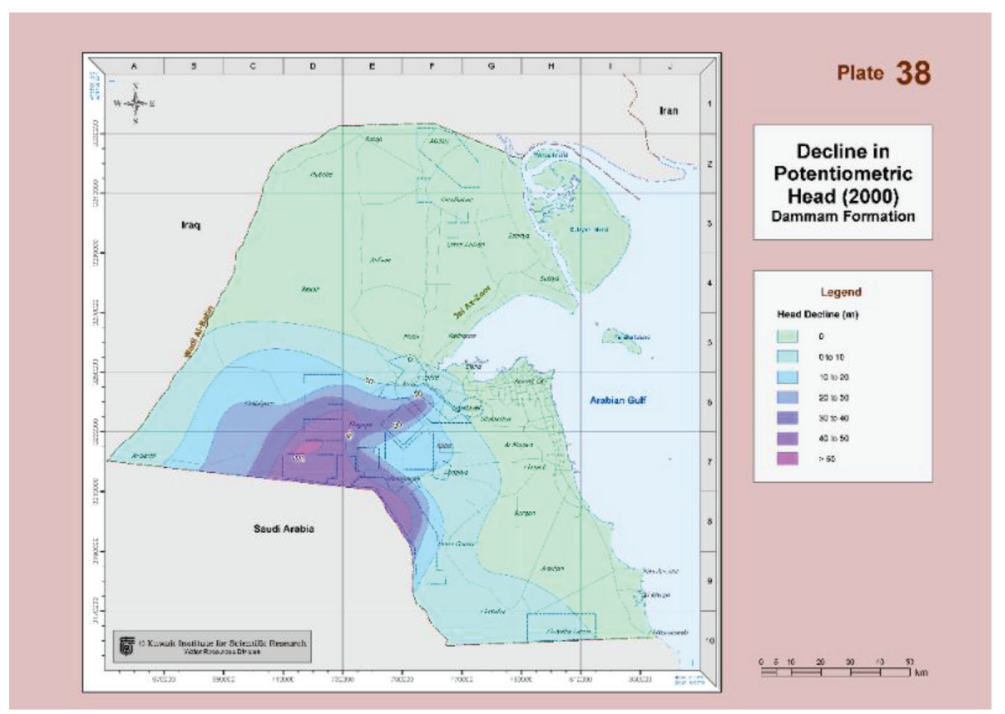

Figure 6: Drawdown in the Dammam Formation aquifer in Kuwait in 2000. 
will be increased in future with increases in consumption, and the treatment capacity will also be increased to keep pace [2]. The treated water is planned to be used for irrigation, artificial recharge of the aquifers, and recreational purposes.

\section{FUTURE DEMAND FOR WATER}

The projections of freshwater demand, carried out by Burney et al. [2] have indicated that by 2025 , the freshwater demand could be anywhere in the range of $722 \mathrm{Mm}^{3} / \mathrm{y}\left(2 \mathrm{Mm}^{3} / \mathrm{d}\right)$ to $3036 \mathrm{Mm}^{3} / \mathrm{y}\left(8.3 \mathrm{Mm}^{3} / \mathrm{d}\right)$. Desalination plant capacity, beyond that available in 2000 , would range between $1.2 \mathrm{Mm}^{3} / \mathrm{d}$ and $9.1 \mathrm{Mm}^{3} / \mathrm{d}$. By 2014 , desalination capacity was already augmented to $2.4 \mathrm{Mm}^{3} / \mathrm{d}$. Further increase in the desalination capacity will depend on the population and economic growth rates in the country.

No detailed study on the historical growth of brackish water demand in Kuwait and its projection for the future has been carried out so far. In view of the availability of treated municipal wastewater for irrigation, production from the brackish water fields has been reduced since 2006 (Fig. 6). These production figures do not, however, take into account the production in the two farm areas (Wafra \& Abdali), where current withdrawal is estimated to be in the range of $300,000-400,000 \mathrm{~m}^{3} / \mathrm{d}[2]$.

\section{AVAILABLE OPTIONS FOR RATIONALIZATION OF WATER DEMAND}

Simultaneous adoption of more than one method for the control of water consumption and the preservation of this important resource will be necessary to manage the water resources available in the country optimally [2]. Some of the important steps that may be adopted are summarized subsequently.

\subsection{Reduction in subsidy}

Rising per capita income together with government-fixed low price have been responsible for a steep rise in average per capita water consumption (from around $113 \mathrm{l} / \mathrm{d} / \mathrm{capita}$ in 1970 to a maximum around $500 \mathrm{l} / \mathrm{d}$ /capita in 2002) [2]. To rein this steep rise in water use, a substantial reduction in the subsidy should be one of the methods high on the agenda and considered in earnest.

\subsection{Immigration control}

Besides the rise in per capita consumption, the increase in population is another major factor in the rise of Kuwait's water consumption (Fig. 4). Since major part of the growth in population was due to the influx of expatriate workers and their families, the future immigration policy of the government should have a significant impact on the rate of rise of water demand in the country.

\subsection{Use of reclaimed municipal wastewater}

One of the possible alternatives for the use of high-quality, desalinated freshwater for gardening and other outdoor use (e.g., car washing) is the use of reclaimed municipal wastewater for gardening and other non-potable uses [2]. A total of 317,297 $\mathrm{m}^{3} / \mathrm{d}$ of treated wastewater was used for agriculture and landscaping in the year 2005 that amounted to $76 \%$ of the treated wastewater generated in that year [5]. This is a welcome sign which will conserve costly freshwater and brackish groundwater to a substantial extent. 


\subsection{Use of water produced by dewatering wells}

The return water from irrigation of private and public gardens, and leakage from septic tanks, the water distribution network and the sewage network have caused rise in groundwater level in the urban areas of Kuwait [7]. A pilot project to study the effectiveness of drainage wells in combating the problem has been completed [8]. With the full-scale implementation of the drainage of subsurface water, a large volume of water will be extracted in the residential areas of Kuwait. Depending on the quality of the produced water, it can be reused for irrigation either directly, or after some processing [2].

\subsection{Artificial recharge of aquifers}

In 2014 , on average, $600,000 \mathrm{~m}^{3} / \mathrm{d}$ excess capacity was available in the desalination plants. A part of this idle capacity may be utilized in producing water, especially during the winter months, that could be stored in the aquifers through artificial recharge for later use during a high demand period or in an emergency. The high-quality membrane (RO)-treated wastewater can be another source of water for recharge.

\subsection{Exploration and development of new water resources}

The following possible sources of additional water may be investigated in Kuwait: a) runoff harvesting; b) usable water in the aquifers under the Arabian Gulf; c) recovery of water from the unsaturated zone; and d) treatment of oilfield produced brine to produce usable water. More elaboration on each of the possibilities follows.

\subsubsection{Runoff harvesting}

In the urban areas, manmade covered areas (roofs, paved roads and parking lots) prevent rain to infiltrate downwards and the non-evaporated parts of the rainfall generally flows into the stormwater network. This type of runoff collection can be relatively easily implemented in the urban areas of Kuwait.

In the nonurban areas of Kuwait, when the rainfall intensity is relatively high, substantial volumes of runoff can be generated in dry channels (wadis) that concentrate the surface flows from surrounding areas and discharge the generated flows to the depressions where the wadis terminate. The water harvesting can be done from these channels or from the terminal depressions.

\subsubsection{Exploration of submarine aquifers}

It has been surmised that significant volume of brackish- to freshwater might have recharged the aquifers below the Arabian Gulf during the last pluvial period when these aquifers were exposed to the surface. This water may still be locked up there by the overlying finer grained sediments, deposited during the transgression of the sea at the end of the Ice Age. Besides, recent recharge of some of these aquifers from the Euphrates-Tigris valley in the north and by infiltrating rainfall along the Iranian coast to the northeast is also possible [9, 10]. Seismic interpretation has indicated the presence of a structural high below the Failaka Island [11] that will be potentially suitable for upwelling of freshwater recharged in the Zagros Mountains, if at all it takes place (Fig. 7a). Two paleochannels have been found that run almost West to East across the Kuwait Bay and south of Bubiyan Island, and continue on both sides of Failaka (Fig. 7b) [11]. The existence of usable paleogroundwater bodies in these channels or elsewhere remains possible. 


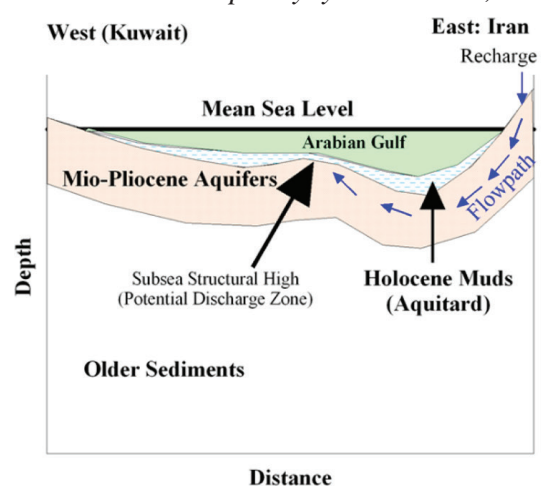

(a)

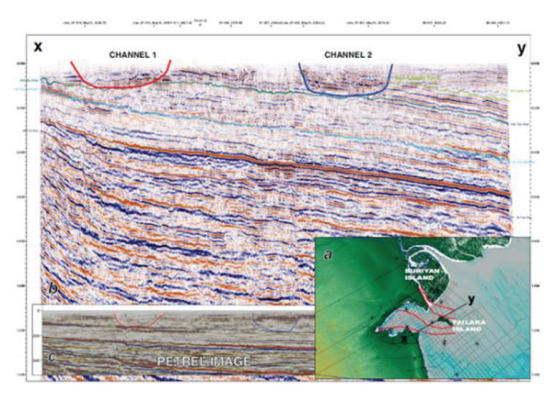

(b)

Figure 7: (a) Conceptual model of upwelling of groundwater in the offshore areas of Kuwait; (b) Seismic section showing paleochannels in the offshore of Kuwait.

\subsubsection{Recovery of water from the unsaturated zone}

Recovery of water from the unsaturated zone near an urban area utilizing renewable energy like solar power, as proposed by Loo and Luk [12], is an innovative idea and is worth trying in Kuwait.

\subsubsection{Treatment of oilfield brine to produce usable water}

El-Sayed et al. [13] investigated the possibility of treating the huge volume of brine produced in the oilfields of Kuwait to make it usable and at the same time to recover various salts that can be commercially marketed. The aim would be to achieve quality level that will ensure $100 \%$ utilization of the recovered water and to have zero liquid discharge (ZLD) to the environment at the end of the treatment.

\subsection{Water linkage of the GCC countries}

As noted by Burney et al [2], by linking the water networks of the Gulf Co-operation Council (GCC) countries, it should be possible to compensate any shortfall (temporary or long-term) in one country by the excess capacities available in others and to rationalize the water use in all of the countries of the region.

\subsection{Conservation and protection measures}

Burney et al. [2] have also advocated for the implementation of measures to protect the available water resources from human activities, environmental degradation and overuse to maximize the utility of the available water resources in the region. As suggested by them, installation of water-saving equipment at the consumer end, introduction of drip irrigation and sprinklers for irrigation of private and public gardens, and limiting the timings of irrigation should save a large volume of water [2]. Protection of groundwater from anthropogenic activities like agricultural development and exploration, production and refining of oil should be pursued with earnest. Renovation of already polluted groundwater should be another goal. The contamination of the desalinated water from the leakage of the distribution pipelines, and intentional or unintentional pollution of the freshwater in the surface reservoirs are also to be guarded against. 


\subsection{Reduction of network loss}

A large volume of water is lost through leakage in the water distribution network and preventive maintenance of the network is one way to minimize such loss [2]. Besides, the adoption of steps like the replacement of asbestos pipes with ductile pipes, application of cathodic protection to the network, reduction of network pressure and installation of automatic leak detection facilities should help reduce network loss substantially [2].

\subsection{Legislation}

Appeals for voluntary reduction of water use and the implementation of conservation measures may not be very successful. Guidelines and restrictions on water use may need to be imposed on water users through legislation to achieve the fall in demand.

\subsection{Institutional measures}

Systematic collection and storage of all data and information related to water production and water use, ensuring the accuracy of these data and periodic review of these data and information by the water authorities of the country, should lead to the adjustment in the water management policy that will be beneficial for the country [2]. Motivating the public for implementation of water conservation measures at residences and places of work through media campaigns should also be the responsibility of these authorities [2].

\subsection{Adoption of new technologies}

Kuwait has shown in the past a high commitment toward the adoption of new technology like multi-stage flash (MSF) and electrodialysis to desalinate seawater and brackish groundwater, respectively, to meet the water requirements of the country. Currently, the application of nanofiltration as a preprocessing method that will make the high-temperature MSF distillation possible is being looked into. The MEW is currently considering the possibility of erecting an RO unit for the desalination of seawater. As mentioned earlier, Kuwait Institute for Scientific Research (KISR) is also investigating the ZLD technology for renovation of oilfield brine. The implementation of these new technologies will certainly make additional resources available for use.

\section{CONCLUSIONS}

Kuwait depends heavily on seawater desalination for its freshwater needs. Brackish groundwater is exploited for agricultural and greening purposes and for mixing with desalinated water to make it potable. Water demand is escalating at a rapid rate under the increasing population pressure and rise in the standard of living. A substantial investment to augment the desalination capacity will be required to meet the increasing demand [2]. The withdrawal of brackish groundwater is also causing excessive stress in the aquifers. The control of freshwater demand through various means and the replacement of brackish water with renovated wastewater for agricultural and greening purposes are suggested to counter the trend [2]. Strategic storage of water may be created through artificial recharge of aquifers with available excess freshwater that may be recovered during the peak demand period or during an emergency [2]. Exploration and development of new types of water resources should also be 
pursued to broaden the water resource base of the country. Linkage of the water networks of all the GCC countries, installation of water-saving devices at the consumer end of the water network, prevention of water pollution, reduction of network loss, and adoption of new technologies for the production and treatment of water, as suggested by Burney et al. [2], should enhance the available water resources. Rationalization of water use through new legislation and increasing the level of public awareness of the strategic nature of water and need for its sustainable use are expected to yield positive results.

\section{ACKNOWLEDGEMENT}

The permission for presentation of the paper from the management of the Kuwait Institute for Scientific Research is gratefully acknowledged (Publication No.: KISR13943).

\section{REFERENCES}

[1] MEW, Statistical year book: water, ministry of electricity and water. Kuwait, pp. 259, 2015.

[2] Burney, N., Mukhopadhyay, A., Al-Mussallam, N., Akber, A. \& Al-Awadi, E., Forecasting of freshwater demand in Kuwait. The Arabian Journal for Science and Engineering, 26(2B), pp. 99-113, 2001.

[3] Al-Sulaimi, J., Viswanathan, M.N., Szekely, F. \& Naji, M., Geohydrological studies of Al-Wafra and Al-Abadally farm areas (Report No. KISR4404). Kuwait Institute for Scientific Research, Kuwait, 1994.

[4] Al-Sulaimi, J., Viswanathan, M.N., Naji, M. \& Sumait, A., Impact of irrigation on brackish groundwater lenses in northern Kuwait. Agricultural Water Management, 31, pp. 75-90, 1996. http://doi.org/10.1016/0378-3774(96)01237-1

[5] Shahalam, A. M., Ahmed, M.E. \& Al-Haddad, A., Wastewater resources in Kuwait: effluent quantity and reuse demand, Kuwait Institute for Scientific Research and Kuwait Foundation for Advancement of Sciences, Kuwait (in press).

[6] Abdel-Jawad, M., Eltony, N., Al-Shammari, S. \& Al-Atram, F., Municipal wastewater desalination by reverse osmosis (Report No. KISR5224). Kuwait Institute for Scientific Research, Kuwait, 1997.

[7] Hamdan, L. \& Mukhopadhyay, A., Numerical simulation of subsurface water rise in Kuwait City. Groundwater, 29(1), pp. 93-104, 1991.

[8] El-Nahhas, F., Sherif, M., Abdullah, W., Hadi, K. \& Ghoneim, H., Long-term operation, monitoring and assessment of the drainage system at Shamiyah and Kaifan, Part 1: Main report (Report No. 5840), Kuwait Institute for Scientific Research, Kuwait, 2000.

[9] Mukhopadhyay, A. \& Fadlelmawla, A., Potential of freshwater reserves under Kuwait territorial water. 34th International Geological Congress (IGC), Brisbane, Australia, 2012.

[10] Kotwicki, V., Akber, A., Akbar, B., Husain, R., Al-Fares, A., Al-Matar, B., Hussain, T., Singh, P., Hussain, F., van Opstal, R., Groen, J. \& Breman, E., Study of Palaeogroundwater Potential Offshore of Kuwait (Report No. KISR11954), Kuwait Institute for Scientific Research, Kuwait, 2014.

[11] Mukhopadhyay, A. \& Al-Khalid, A., Initial assessment of paleogroundwater potential in offshore of Kuwait (Report No. KISR12874), Kuwait Institute for Scientific Research, Kuwait, 2015. 
[12] Loo, W.W. \& Luk, M.Y., Economical new water sources for world urban centers, 2nd International Conference on Sustainable Urbanization, Hong Kong, China, 2015.

[13] El-Sayed, E., Al-Tabtabaei, M., Safar, M., Al-Shammiri, M., Bou-Hamad, S., Ahmed, M., Al-Mesri, A., Al-Jabli, H. \& Al-Saffar, A., Treatment of oil-produced saline water for cost-effective water recovery and its sustainable use (Phase-I) (Report No.: KISR9385), Kuwait Institute for Scientific Research, Kuwait, 2008. 